\title{
Main pests of mung bean and the effectiveness of chemicals use in pest management
}

\author{
Shahnoza Makhmudova $^{1^{*}}$ and Khonoyim Ergasheva ${ }^{1}$ \\ ${ }^{1}$ Tashkent State Agrarian University, 100140 Tashkent province, Uzbekistan
}

\begin{abstract}
In this paper, our studies have shown that a total of 27 species of pests belonging to 7 classes of 2 genus occur and cause damage in replanted mung bean agrobiocenosis. The highest biological efficiency in the cultivation of alfalfa in Mung bean is Entolucho $20 \%-0.31 /$ ha, Bagira $20 \%-0.3 \mathrm{l} / \mathrm{ha}$, Karache Duo 25\% - $0.3 \mathrm{l} / \mathrm{h}$. When using chemicals in the amount of BI-58 (new) $40 \%-1.0 \mathrm{l} / \mathrm{ha}$, Imidogold 35\% - $0.25 \mathrm{l}$, Lamdex SC $5 \%-0.51 /$ ha against bruxus, more than $85-90 \%$ biological efficiency was achieved in our research.
\end{abstract}

\section{Introduction}

Legumes, which are the mainstay of the world's agriculture, are a much-needed food product by the human body because they are rich in essential proteins, fats and carbohydrates. Today, the world produces a total of 62 million tons of legumes per year as food. Accordingly, one of the urgent tasks is to study the species composition, bioecological characteristics, distribution and damage of pests, which cause a sharp decline in yields of mung bean planted in the second period, and to implement the results of research on their quantification and implementation $[1,2]$.

According to the Secretariat of The International Plant Protection Convention (IPPC), part of the FAO, the United Nations Food and Agriculture Organization, 20-40\% of agricultural crops are lost each year due to plant pests and diseases. Referring to the literature in Uzbekistan, a number of pests cause damage to the mung bean crop in the field and during storage in warehouses, resulting in the death of $40-50 \%$, and in some years the damage is even greater $[3,4]$.

Mung bean ((Phaseolus aureus Piper) and Vigna radiata (L) Wilczek according to the latest classification) is the most common crop in the world and it is valuable for food. Mung bean grain contains $24.8 \%$ protein, $1 \%$ fat, $3.5-4.5 \%$ fiber, $4.5-5.5 \%$ ash and $62-65 \%$ carbohydrates, $50.4 \%$ carbonates, $1.5 \%$ fatty acids, A, B1, B2, B3, B6, B9, C, E, and K vitamins, sodium, phosphorus, potassium, magnesium, copper, zinc minerals, and antioxidants $[5,6]$.

Mung bean improves soil fertility; its roots accumulate nitrogen-fixing bacteria during the growing season. During the growing season, under favorable weather conditions, it can accumulate up to $200 \mathrm{~kg}$ of nitrogen per hectare. Therefore, it is recommended to plow the

* Corresponding author: shakhnoza.makhmudova@yandex.ru 
land, leaving the roots of mung bean on the ground. Mung bean is a drought-resistant, resource-efficient crop that does not require large expenditures to grow [7,8].

In the crop rotation system, mung bean is a good past crop. Mung bean is advisable to be used as a secondary crop after cereals and vegetables. The mung bean crop increases the yield of almost all self-grown crops and blends well with all agricultural crops [4].

One of the key factors in obtaining a high and quality crop from a mung bean plant is protection from pests that cause serious damage to crops and are of high economic importance [6].

Mung bean is mainly grown as a secondary crop on lands devoid of autumn cereals, potatoes, vegetables and other crops plowed in the fall for planting in the spring, stormed in early spring. Before planting, weeds are multiplied and cultivated en masse when the soil is compacted. When planted in a pit, the previous crop is harvested and the land is irrigated. When the soil is ripe, it is plowed to a depth of 22-25 cm. Before plowing, 40-60 kg of phosphorus and 20-40 kg of potassium are applied per hectare. During the flowering and flowering period, $20-30 \mathrm{~kg}$ of phosphorus and 10-20 kg of potassium are added. Nitrogen fertilizers are applied when the soil is humus and low in nitrogen [7,8]. Nitrogen fertilizers can be applied during the growing season, the norm is $20-30 \mathrm{~kg}$ in pure form. If the norm of nitrogen fertilizer is exceeded, biological nitrogen is not assimilated.

In recent years, in all districts of the regions of the country, the sowing of mung bean, soybean and bean crops has been increasing after the grain crops. Unfortunately, these crops are also affected by a number of special and omnivorous pests in the field and during grain storage, leading to reduced yields. According to the data obtained, it is known that stored legumes, especially mung bean and bean grains, are killed by $80-90 \%$ with graineating bruxus. It is very important to determine the cause of these problems, to identify the types of pests found in replanted mung bean and other crops belonging to the same family, to manage their quantity by studying the bioecological characteristics of dominant species $[9,10]$.

Despite the fact that the species, distribution, development of pests in legumes have been studied to some extent and methods of their control have been partially developed, specific pests of legumes (grain growers, mines, and canes) have not been studied enough [10].

Among the main pests of legumes grown in Uzbekistan, he focused on the long-nosed beetles, pea pods, bean pods, pea pods and pea juice, and provided information on their biology. Among them, special attention was paid to the long-nosed snails, which showed that they were damaged by worms as well as beetles [11].

In the Mung bean crop, 3 species of beetles belonging to the family Bruchidae are known today, including pea beetle (Bruchus pisarum Z), bean beetle (Acanthoscelides altectus Sag), and four-spotted beetle (Callosebruchus maculates Z). The mature breeds of these grain growers develop in the field, and the larvae develop in the grain in warehouses, and plant grains severely damaged by grain growers become absolutely unfit for planting or consumption [2].

Mature breeds of donkeys emerge by opening holes 2-3 $\mathrm{mm}$ in size in the seed walls. In this case, the harvest will be unfit for consumption and planting. As a result, the germination of pea grains decreases from $10 \%$ to $90 \%$ [12]. Other researchers have suggested that pea grains overwinter in contaminated grain until spring next year [13].

Studies by Sumeet et al have shown that 15 to $20 \%$ of pea grains can be damaged in fields where peas are heavily infested. Grain larvae eat $25 \%$ of the affected grains and such grains shed before ripening [12].

According to Sumeet and others, Bruchus pisorum is one of the most dangerous pests of peas, which was first identified in 1964 in South Africa. Although this pest is called a pea farmer, its lifestyle is not the same as that of warehouse and rice farmers. The difference 
between this pest and other grain growers is that pea grain does not multiply in warehouses. Pea grains stored in a warehouse can only continue to grow in a warehouse if the plant is damaged during the growing season [12].

There are 3 types of pests belonging to the genus Hemiptera, in which alfalfa is common. As a result of the plant's sucking of the flowerpot during flowering and flowering, the flowers fall off and the pods do not develop fully. In Uzbekistan, there are currently 3 species of mung bean, including field lynx (Lygus pratensis L), alfalfa lynx (Adelphocoris lineolatus Goes) and cotton cannon (Creontiades pallidus Rafmb) in Surkhandarya province of Uzbekistan [5].

In our research, it was observed that in areas strongly affected by handcuffs, the flowers of the mung bean shed and the pods did not form. When planted as a secondary crop, their damage is doubled. In our study, the average loss of herbivores in Tashkent region was 42.7-48.4\%.

A. Lineolatus is the main pest of alfalfa, mung bean, soybean, bean crops. It damages the seeds and crop marks of plants and reduces their quality. It causes early flowering of alfalfa flowers and drying of growing seeds. In the U.S. city of Manitoba, plants were found to be severely damaged by alfalfa caterpillars (A. Lineolatus). There, alfalfa is grown on 8,500 hectares for seed and about 3.5 million $\mathrm{kg}$ of seeds are harvested [13].

According to the literature, alfalfa canopy in Central Asia has resulted in a 10-14\% loss of yield due to damage to legumes. The most serious damage occurred during the drought years, when the rate of damage to plants by pests increased. In plants, all buds stopped developing when the pest density was $250-300$ per 100 bushes, and $32 \%$ of buds stopped growing when there were $35-40$ pests per 100 bushes [2].

As can be seen from the above problems, one of the most pressing issues today is the development of highly effective control methods by re-examining the species composition of reptile mung bean pests and studying their bioecology.

\section{Materials and methods}

The research was conducted in 2017-2019 in the experimental fields of "Hakimjon Fayzli Boghi" Farm in Yangiyul District, Tashkent province; "Nurmuhammad Ishon" Farm, Qibray District, Tashkent province, Botanical Research Institute, Tashkent State Agrarian University, Center for Innovative Developments and Consulting in Agriculture, and "Husanjon Sanjar" farms in Akkurgan District, Tashkent province of Uzbekistan.

The distribution area of mung bean pests in the regions of the republic was studied on the basis of directional observations. Their species composition was determined with the help of experts on the basis of samples collected from the field. Dominant species of pests were selected and their bioecological characteristics were studied. Phenological observations of pests were carried out in the laboratory and on lysimeters to study the conditions under which they overwinter, the favorable air temperature and relative humidity for growth, the fertility of pests and which plants grow well.

In each region, their degree of infestation of legumes and the density of pest populations in the regions were determined. When observing pests of legumes, their main predatory and parasitic entomophagous species are studied and collected. Among them, species that are important in reducing the number of pests were identified, and additional information on their bioecology was collected. All observations and calculations were carried out according to the method of MI Rashidov and others [1]. At the same time, samples were taken from each controlled field once every 10 days from early spring to the end of the season. In order to account for entomophages, infected insects were collected from experimental fields and the percentage of parasites released from them was determined. Predatory entomophagous species and their populations and densities were determined by 
taking into account parasites and predators derived from infected insects collected using entomological traps. This calculation and observation [1] was carried out according to Rashidov's method. To determine the number of entomophagous (beetle and larvae of coccinellids, goldfish larvae) samples were taken with an area of $25 \times 25 \mathrm{~cm}$ and averaged at $1 \mathrm{~m}^{2}$. Calculations were performed every $3,7,10$, and 15 days before and after processing [7].

\section{Results and discussion}

According to the results of research conducted in Tashkent province, in the agrobiocenosis of mung bean planted in the second period, 4 species belonging to the genus Orthoptera, followed by, 6 species to the genus Soleoptera, 3 species to the genus Homoptera, 3 species to the genus Homoptera, 3 species to the genus Diptera, 1 species to the genus Diptera, 5 species to the genus Lepidoptera, and 1 species to the genus Thysanoptera. 1 species of pests belonging to the genus Arachnoidea (Asariphormes) was recorded. The study found that a total of 27 species of pests belonging to 7 classes of 2 genuses were encountered and damaged in replanted mung bean agrobiocenosis (Table 1).

Table 1. Types of pests identified in the agrobiocenosis of mung bean planted in the second period in 2017-2018 (Botanical Research Institute of Qibray district, Tashkent province, 2017-2019).

\begin{tabular}{|l|l|l|}
\hline$\#$ & Name of species & Occurrence \\
\hline 1 & Agrotis segetum Schiff. & +++ \\
\hline 2 & Phytometra confuse Steph & + \\
\hline 3 & Heliothis armigera Hb. & +++ \\
\hline 4 & Agrotisconspicua Hb. & ++ \\
\hline 5 & A.exclamationis. L & + \\
\hline 6 & Liriomysa cicerina Rond. & ++ \\
\hline 7 & Setona crinitus Hbst. & ++ \\
\hline 8 & Setona cylindricollis Fahr. & +++ \\
\hline 9 & Clon cerambycinus & ++ \\
\hline 10 & Agriotes meticulosus Cand. & +++ \\
\hline 11 & Dailognatha nasute Men. & + \\
\hline 12 & Callosebruchus maculates Z. & +++ \\
\hline 13 & Aphis fabae Scop. & ++ \\
\hline 14 & Aphis medicaginis craccivora Koch. & +++ \\
\hline 15 & Aphis gossupi Glon. & + \\
\hline 16 & Acyrthosiphon gossypii Mordv. & ++ \\
\hline 17 & Carpocoris fuscispinus Boh. & +++ \\
\hline 18 & Lygus pratensis L. & +++ \\
\hline 19 & Adelphocoris lineolatus Goes & +++ \\
\hline 20 & Trialeurodes vaporariorum Westw. & +++ \\
\hline 21 & Odontothrips intermedinsUzel. & + \\
\hline 22 & Dociostaurus maroccanus Thunb. & ++ \\
\hline 23 & Dociostaurus kraussii Lng. & ++ \\
\hline 24 & Colliptamus italicus L. & + \\
\hline 25 & Tettigonia viridissima L. & +++ \\
\hline 26 & Tetranychus urticae Koch. & +++ \\
\hline & & \\
\hline
\end{tabular}

Note: + - rare, ++ - moderate, +++ - most common occurrence.

Mung bean differs from other leaf pests by its damage to spiders in agrobiocenosis. This pest causes great damage to a number of agricultural crops, including legumes, especially 
mung bean and soybeans. The pest is common in areas planted with mung bean and soybeans, mainly when the plant produces 4-5 leaves, settles on the back of the leaves and feeds by sucking plant sap. The surface of the damaged leaves reddens and dries out, resulting in the grains becoming useless without ripening. There are several species of pests belonging to the genus Lepidoptera. The most important of these are autumn and cotton nights.

Autumn nightshade (Agrotis segetum Schiff) is one of the most common pests in irrigated lands. This pest damages the roots and young shoots of legume crops, causing seedlings to thin out and the crops to die at young seedlings. Cotton nightshade (Heliothis armigera $\mathrm{Hb}$ ) is a dangerous pest of several agricultural crops, including legumes. Cotton nightshade is widely distributed in legume crops such as peas and beans, severely damaging their grains during the milk ripening period and killing many.

Two species of beetles (Soleoptera) belong to the genus Soleoptera: the grass beetle (Sitona crinitus Hbst) and the spotted pea beetle (Sitona linellus Bansd) are common in legume crops. These beetles destroy legume crops planted in early spring by damaging the first leaf, growth point, and seed coat of grass. It lays its eggs scattered on the soil surface and rarely on the plant. The larvae that hatch from the eggs develop by feeding on nitrogenfixing nodules in the roots. Mung bean yields more than $50 \%$ of the yield and blue mass when severely damaged by the end long noses.

Today, 3 species of beetles belonging to the family of mung bean beetles (Bruchidae) are known, of which the pea beetle (Bruchus pisarum Z), the bean beetle (Acanthoscelides altectus Sag) and the four-spotted beetle (Callosebruchus maculates Z) are severely affected. The mature breeds of these grain growers develop in the field, and the larvae in the grain in the barns, and the grain of the plant, which is severely damaged by the grain, becomes absolutely unfit for planting or consumption.

There are 3 types of pests belonging to the genus Candida, of which the field Candida is the most common. In general, in the legume crops of Uzbekistan there are alfalfa blind handles (Adelphocoris lineolatus Goes), field blind handles (Lygus pratensis L) and sharp shoulder handles (Sarpocoris coreanus iranus) [7]. Mature breeds and larvae of these pests cause damage by feeding on the pods, leaves and young twigs of legumes.

Among the pests encountered in the mung bean crop, the economic damage of today's herbivore shackles is increasing. It should be noted that at the present stage of research, both the type of insecticides and acaricides recommended, as well as some work has been done to improve the system of pest control. Their use allows to reduce the size of chemically treated areas and to preserve the crops grown.

In order to determine the use of systemic drugs against pests in the Mung bean crop and to determine their biological effectiveness, a number (Entolucho, 20\% - 0.3 1/ha, Bagira $20 \%-0.31 /$ ha and Karache Duo 25\% - 0, 3 1/ha) we tested the chemicals. Spraying of plants infested with plant handcuffs was carried out in a motorized hand-held device at a temperature of $25-280 \mathrm{C}$ in the afternoon, consuming 300 liters of working fluid per hectare. Calculations were performed every 1, 3, 7 and 14 days before and after spraying. Biological efficacy was performed according to the Abbot formula. The results of the initial experiments are shown in Figures 1 and 2 below.

According to the figure, when Entolucho was used against alfalfa at a rate of $20 \%$ to 0.3 1/ha, the biological efficacy was $84.7 \%$ and $94.3 \%$ at 14 days after spraying, 3 days after spraying. In the case of Bagira $20 \%-0.31 /$ ha $-0.31 /$ ha, this figure ranged from $85.7 \%$ to $95.4 \%$. In the Karache Duo $25 \%$ - 0.31 /ha consumption rate, the number of handcuffs was found to be $87.0 \%-92.3 \%$ lower than the control. The results of the experiments showed that the tested drugs were highly effective against alfalfa. When insecticides against alfalfa are used in scientifically justified periods, the biological effectiveness is higher than $90 \%$ by 14 accounting days. 


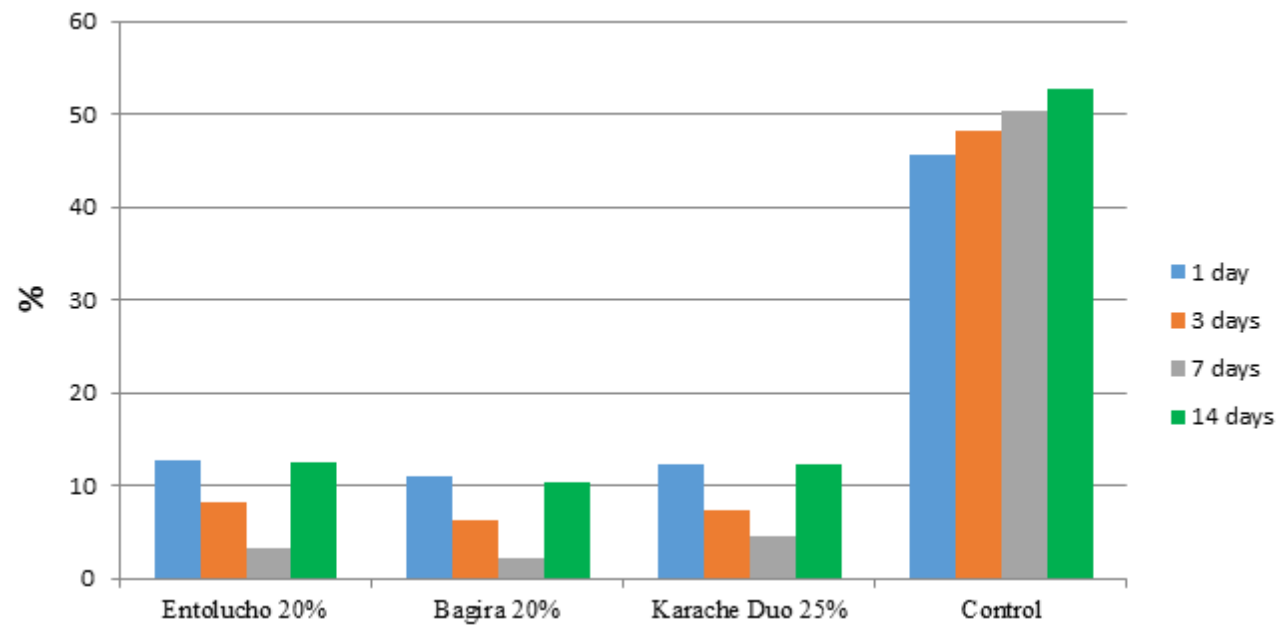

Fig. 1. Effectiveness of chemical preparations against mung bean pests (Field experiment, Experimental farm of Botanical Research Institute, May 22, 2018).

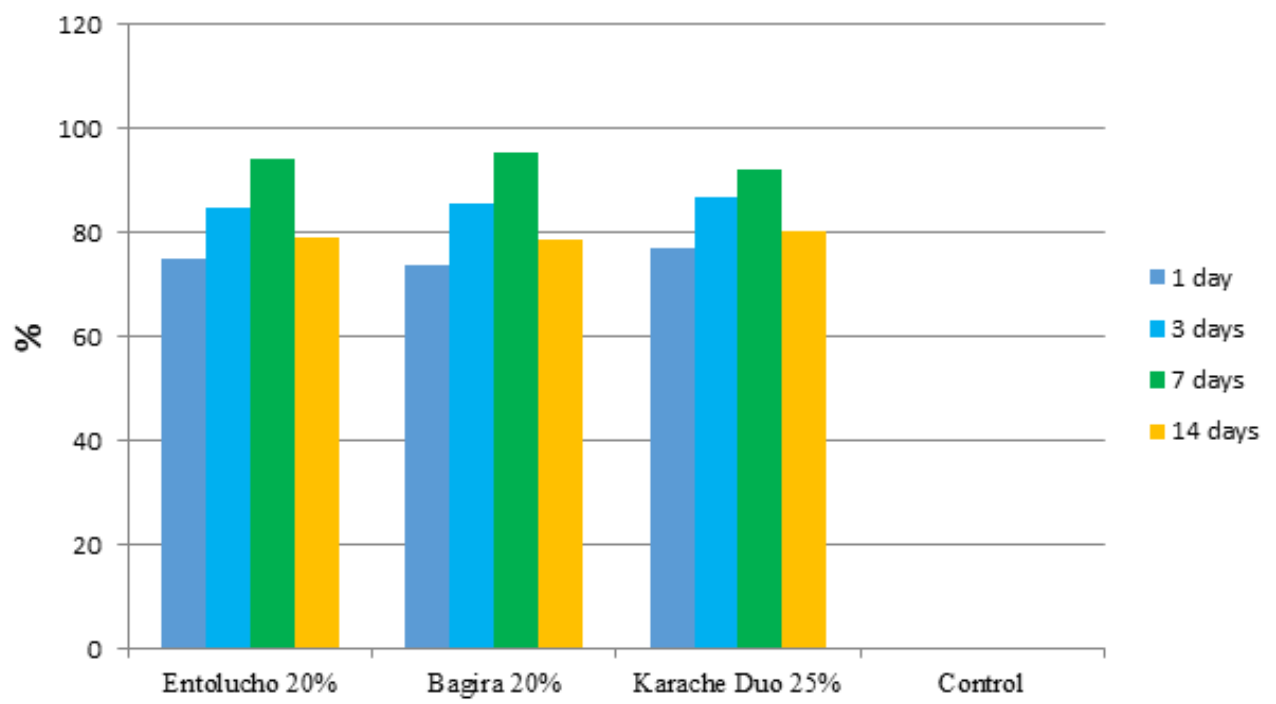

Fig. 2. Biological efficacy of chemical preparations against mung bean pests (Field experiment, Experimental farm of Botanical Research Institute, May 22, 2018).

The most damaging pest of modern mung bean grains during storage is the grain bruxus. Grain bruxes cause great damage to farms specializing in the cultivation of legumes in all regions of the country. Grain bruxes cause great damage in the field and in the process of storing grain in warehouses and private homes; the damaged grain remains absolutely unfit for planting and consumption.

Taking into account the above, in order to protect the mung bean from predators, against its mature breeds (beetles) BI-58 (new) 40\% - 0.5-1.0 1/ha, Imidogold 35\% $0.2-$ 0.25 1/ha. e, Lamdex SC 5\% - 0.4-0.5 1/ha consumed chemicals. Each variant of our experiment was conducted in 3 repetitions. In the control variant, it was not treated with insecticides. According to the results of the study, when BI-58 (new) was applied at $40 \%$ - 
$0.51 /$ ha, $48.9 \%$ of the biological efficiency was achieved on the $3 \mathrm{rd}$ day of the calculation, and on the 7th day of the calculation, the biological efficiency reached $78.9 \%$. .

According to our research on the Mung Bean crop, the highest biological efficiency was observed on the 14th day of accounting and was $89.4 \%$, while when using this drug at a rate of $1.0 \mathrm{l} / \mathrm{ha}$, the highest biological efficiency was achieved on the first day of the account at $54.2 \%$. On the 14 th day it was $92.0 \%$, the efficiency decreased slightly in the remaining accounting days.

In the next Imidogold $35 \%-0.2$ / ha consumption variant, the biological efficiency was $47.5 \%$ compared to the control on the first accounting day, while on the 7 th accounting day this indicator was $73.8 \%$ compared to the control, and on the 14 th day $-86.6 \%$, Imidogold $35 \%$ - in the variant used at the rate of $0.251 / \mathrm{ha}, 53.6 \%$ on the first day, $75.0 \%$ on the 7 th day, $88.2 \%$ on the 14 th day and $14-86.3 \%$ in the reporting days.

In the variant where Lamdex SC 5\% was applied at a rate of $0.41 /$ ha, on the first day of the calculation the biological efficiency was $50.4 \%$ compared to the control, on the 7 th day of the calculation $64.9 \%$ and on the 14 th day of the calculation $-79.1 \%$. In our last variant, Lamdex SC - $0.51 /$ ha, the biological efficiency was $52.4 \%$ on the first day of calculation, while the maximum efficiency was $88.6 \%$ on the 14 th day.

When selecting high-performance experimental options in 2017, BI-58 (new) was tested in a large experimental field in 2018 at a consumption rate of 1.0 1/ha, Imidogold 35\% 0.251 Lamdex SC 5\% - 0.5 1/ha In our experimental variant, when BI-58 (new) was treated at $1.0 \mathrm{l} / \mathrm{ha}$, the maximum biological efficiency was reached on the 14 th day of the calculation, reaching 93.3, while in the remaining variants, the biological efficiency was 91.1 to $90.4 \%$. In the following days of the account, a slight decrease was observed.

In summary, BI-58 (new) 40\% - 1.0 1/ha, Imidogold 35\% - 0.25 l, and Lamdex SC 5\% $0.51 /$ ha were used in the mung bean crop against grain bruxus. More than $85-90 \%$ biological efficiency is achieved when using chemicals (Table 2).

Table 2. Biological efficacy of insect acaricides against dung beetle in mung bean crop (Botanical Research Institute of Qibray district of Tashkent province 2017-2018).

\begin{tabular}{|c|c|c|c|c|c|c|c|c|c|c|}
\hline \multirow{3}{*}{ Options } & \multirow{3}{*}{ 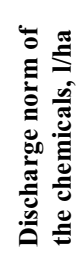 } & \multicolumn{5}{|c|}{ Pests in $1 \mathrm{~m}^{2}$, pes } & \multirow{2}{*}{\multicolumn{4}{|c|}{ Bio-efficiency, \% }} \\
\hline & & \multirow{2}{*}{ 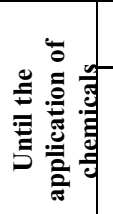 } & \multicolumn{4}{|c|}{$\begin{array}{c}\text { After application of } \\
\text { chemicals, days }\end{array}$} & & & & \\
\hline & & & 3 & 7 & 14 & 21 & 3 & 7 & 14 & 21 \\
\hline \multirow{2}{*}{$\begin{array}{c}\text { BI-58(new) } \\
40 \%\end{array}$} & 0.5 & 8.2 & 4.9 & 2.7 & 1.4 & 1.8 & 48.9 & 78.9 & 89.4 & 87.6 \\
\hline & 1.0 & 6.9 & 3.7 & 2.5 & 0.9 & 1.3 & 54.2 & 76.8 & 92.0 & 89.3 \\
\hline \multirow{2}{*}{$\begin{array}{c}\text { Imidogold } \\
35 \% \\
\end{array}$} & 0.2 & 8.3 & 5.1 & 3.4 & 1.8 & 1.7 & 47.5 & 73.8 & 86.6 & 85.7 \\
\hline & 0.25 & 7.9 & 4.3 & 3.1 & 1.5 & 1.9 & 53.6 & 75.0 & 88.2 & 86.3 \\
\hline \multirow{2}{*}{$\begin{array}{c}\text { Lamdex SC } \\
5 \% \\
\end{array}$} & 0.4 & 6.2 & 3.6 & 3.4 & 2.1 & 2.2 & 50.4 & 64.9 & 79.1 & 79.8 \\
\hline & 0.5 & 7.0 & 3.9 & 2.8 & 1.3 & 2.1 & 52.4 & 74.5 & 88.6 & 83.0 \\
\hline Control & - & 7.6 & 8.9 & $\begin{array}{c}11 . \\
9\end{array}$ & 12.3 & 13.4 & - & - & - & - \\
\hline $\begin{array}{c}\text { BI-58(new) } \\
40 \% \\
\end{array}$ & 1.0 & 6.8 & 3.2 & 1.7 & 0.8 & 0.9 & 60.1 & 84.8 & 93.3 & 93.0 \\
\hline $\begin{array}{c}\text { Imidogold } \\
35 \% \\
\end{array}$ & 0.25 & 7.1 & 3.6 & 2.1 & 1.1 & 1.2 & 57.1 & 81.2 & 91.1 & 91.1 \\
\hline $\begin{array}{c}\text { Lamdex SC } \\
5 \% \\
\end{array}$ & 0.5 & 7.6 & 4.8 & 3.1 & 1.3 & 1.4 & 46.5 & 74.1 & 90.1 & 90.4 \\
\hline Control & - & 7.7 & 9.1 & $\begin{array}{c}12 . \\
1\end{array}$ & 13.4 & 14.7 & - & - & - & - \\
\hline
\end{tabular}




\section{Conclusions}

According to the results of research conducted in Tashkent province, in the agrobiocenosis of mung bean planted in the second period, 4 species belonging to the genus Orthoptera, followed by, 6 species to the genus Soleoptera, 3 species to the genus Homoptera, 3 species to the genus Homoptera, 3 species belonging to the genus Diptera, 1 species to the genus Diptera, 5 species to the genus Lepidoptera, and 1 species to the genus Thysanoptera. 1 species of pests belonging to the genus Arachnoidea (Asariphormes) was recorded. The study found that a total of 27 species of pests belonging to 7 classes of 2 genuses were encountered and damaged in replanted mung bean agrobiocenosis. Among the pests occurred, the main pests are spider mites, autumn moths, cotton moths, and alfalfa caterpillars.

In our studies, Entolucho 20\% - 0.3 1/ha, Bagira 20\% - 0.3 1/ha, Karache Duo 25\% - 0.3 1/ha consumption of alfalfa cannabis in mung bean crop biological efficiency was higher than $90 \%$. BI-58 (new) $40 \%-1.0 \mathrm{l} /$ ha for anti-bruxus, Imidogold 35\% - 0.251 , Lamdex SC $5 \%-0.51 /$ ha, and $85-90 \%$ when using chemicals greater biological efficiency was achieved.

\section{References}

1. N.Ch. Namozov, D.A. Kodirova, M.I. Usmonova, International journal of scientific \& technology research, 9(03), 5491-5493 (2020)

2. K.E. Voronin, Temporary guidelines for the use of efficiency criteria for natural populations of entomophages and entomopathogens, 35-46 (1986)

3. V.E. Kambulin, Fight against insect pests of forage crops and pasture plants, 118-130 (1987)

4. A.T. Kholliev, Scholars Journal of Agriculture and Veterinary Scieces, 448-449 (2016)

5. N.M. Makhmudkhodjaev, M. Isaev, A Harmonized Method of Protecting Plants from Pests and Environmental Protection: A Proceeding of Articles, 123-144 (1994)

6. S. Islamov, N. Namozov, M. Saidova, D. Kodirova, E3S Web of Conferences, 244, 03028 (2021)

7. S. Isaev, I. Begmatov, G. Goziev, S. Khasanov, IOP Conference Series: Materials Science and Engineering, 883(1), 012080 (2020)

8. A. Kholliev, S. Dusmanov, J. Agro-Ilm, 4(32), 45-46 (2014)

9. S.K. Isaev, R.U. Rakhmonov, S.S. Tadjiev, G.I. Goziev, S.Z. Khasanov, IOP Conference Series: Earth and Environmental Science, 614(1), 012147 (2020)

10. S. Isaev, S. Khasanov, Y. Ashirov, T. Karabaeva, A. Gofirov, E3S Web of Conferences, 244, 02012 (2021)

11. R.A. Kulmatov, V.S. Savenko, N. Dalonov, Geochemistry International, 29(5), 140148 (1992)

12. S. Verma, A. Kumar Gupta, N. Mittal, International Jaurnal Current Microbiology and Applied Sciences, 4(8), 474-478 (2015)

13. H. Seyed Mahdi, B. Asadi, K. Kamali, M. Shojai, O. Hadi, Journal of Agricultural sciences, 8(2), 73-94 (2002) 